\title{
A Pilot Study of Significant Environmental Aspects Analysis on Coastal Fishing Port 'Pondokdadap' Malang Indonesia
}

\author{
Agus Dwiyanto $^{1 *}$, Achmad Wicaksono², Bagyo Yanuwiadi ${ }^{3}$ \\ ${ }^{1}$ Master Program of Environmental Resources Management and Development, Brawijaya University \\ ${ }^{2}$ Civil Engineering, Faculty of Engineering, Brawijaya University \\ ${ }^{3}$ Department of Biology, Faculty of Mathematics and Natural Sciences, Brawijaya University
}

\begin{abstract}
This research aimed to analyze significant environmental aspects of Coastal Fishing Port (PPP) Pondokdadap, Malang, East Java. The significant environmental aspect analysis was undertaken as an initial step in implementing the EcoFishing Port concept or managing an environmentally sound fishing port. The analysis was undertaken using the Strategic Overview of Significant Environmental Aspects (SOSEA) method. This method is a method of Ecoports Foundation in identifying the impacts of port management, tailored to the conditions and activities of fishing ports. Based on the results of calculation and analysis of the environmental impact factors with the value range of 1-10, there were 5 (five) significant environmental aspects obtained in the management of PPP Pondokdadap, namely: waste production (7.3); employment absorption (7.0); water pollution (6.8); ship waste production (6.6); and liquid waste (wastewater) production (6.0). In broad outline, significant environmental aspects occur because the prevailing policy and regulation have not been implemented and undertaken in the environmental management activities in $P P P$ Pondokdadap, excluding the aspect of employment absorption occurring within 3-4 months due to natural factors, i.e. non-fish season. Significant environmental aspect management that must be done by the managers of PPP Pondokdadap to realize the Eco-Fishing Port concept implementation include the fulfillment of facility and infrastructure standards according to the prevailing rules, regulation implementation and discipline enforcement, coaching and socialization, continuous environmental aspect monitoring, and procedural preparation of significant environmental aspect management.
\end{abstract}

Keywords: Eco-Fishing Port, PPP Pondokdadap, Significant environmental aspect, SOSEA

\section{INTRODUCTION}

Fishing ports are one type of ports with fishery activities and government activities [1]. Regarding fishery activities, the Ministry of Marine Affairs and Fisheries asserted that there must be food security guarantees along the ongoing production chain in improving the quality of fishery products [2]. In addition, the Ministry of Marine Affairs and Fisheries is responsible for organizing and developing the management of fishing ports, including the aspects of waste, the quality of water, air and land, sedimentation management, landfill, noise, and pollution [3]. The security guarantees and management development of fishing ports can be pursued by managing the ecological aspects of fishing port or also called as environmentally sound fishing port management (Eco-Fishing Port) [4]. The concept of Eco-Fishing Port has

*Correspondence address:

Agus Dwiyanto

Email: agus2yanto@student.ub.ac.id

Address: Master Program of Environmental Resources

Management and Development,

Brawijaya University become a requirement in a fishing port development strategy to support fishery products so as to meet the quality standards [5]. The management of fishing ports with the EcoFishing Port concept is necessary because the activities at fishing ports potentially create negative pressure or influence on the surrounding environment. This is because the increase in the number of production and ships in fishing ports will be directly proportional to the increased potential of waste generated from both land and sea activities [6]. In addition to the implementation of the concept of Eco-Fishing Port, the government and public awareness have an important role in the management of environmentally friendly fishing ports to overcome environmental problems[7].

In the management of fishing ports with the Eco-Fishing Port concept, the first step taken is implementing a significant environmental aspect analysis, according to the procedures of Ecoports Foundation. This analysis is done using the Strategic Overview of Significant Environmental Aspects (SOSEA) designed to help port managers in identifying significant environmental aspects 
and determining environmental management priorities [8].

One of the fishing ports with a high potential of tuna production in East Java is Coastal Fishing Port (PPP) Pondokdadap [9]. However, activities in $P P P$ Pondokdadap is very susceptible to environmental pollution mainly caused by solid and liquid waste that can affect water quality, air quality, and environmental hygiene or cleanliness [10]. The uniqueness of waters area condition around PPP Pondokdadap also becomes a big concern. This is related to the existence of Sempu Island in the east of the port with a nature reverse status and becomes a conservation area for coral reefs influenced strongly by the water condition aspect [11].

Based on the explanation above, it can be concluded that the management of PPP Pondokdadap requires monitoring and handling of the activities in the port that potentially impact the environmental aspects. Moreover, the analysis of significant environmental aspects of PPP Pondokdadap is an initial step of fishing port management with the concept of EcoFishing Port. The purpose of this research was to analyze significant environmental aspects of $P P P$ Pondokdadap to be used by the Port Technical Implementation Unit (UPT) in determining fishing port management priorities.

\section{RESEARCH METHOD}

The research on the analysis of significant environmental aspects of PPP Pondokdadap Malang used a quantitative approach. This research was conducted from January to April 2018. The data related to the environmental activities, impacts, and aspects of the fishing port were collected using a literature and survey research method. In determining the significant environmental aspects and management of the port, this research used the SOSEA matrix and questionnaire forms established by Ecoport Foundation which were then adjusted to the condition of fishing ports in Indonesia. The SOSEA matrix and questionnaire standards of Ecoports Foundation used in this research derived from Darbra (2005), consisting of three parts of the analysis, namely: 1) Significant environmental aspect identification using a matrix of relationship between port activities and the impacts resulted, 2) Strategic and specific questions on significant environmental aspects of fishing ports, and 3) Strategic aspect overview.

The fulfillment of the SOSEA matrix and questionnaires was addressed to the managers of
PPP Pondokdadap through interviews and data comparison of literature and survey results. The questionnaire fulfillment and interviews were only conducted by the respondents who were directly engaged in the management of the fishing port environment.

\section{Research site}

The research site of $P P P$ Pondokdadap is located in Sendangbiru Hamlet, Tambakrejo Village, Sumbermanjing Wetan District, Malang Regency, East Java Province, with geographical position of $8^{\circ} 25^{\prime} 59^{\prime \prime}$ South Latitude and $112^{\circ} 40^{\prime} 55^{\prime \prime}$ East Longitude. The research was conducted in the working and operation area of the fishing port. PPP Pondokdadap is one of Class $C$ (Coastal Fishing Ports) managed by the Government of East Java Province, in this case referring to the Port Technical Implementation Unit of Management of Marine and Fishery Resources (UPT P2SKP) of PPP Pondokdadap.

\section{Identification of PPP Pondokdadap's Significant Environmental Aspects}

The identification of the significant environmental aspects used a matrix of the relationship between activities in the fishing port and the impacts resulted on the environmental aspects of the fishing port. The fishing port activities were divided into two, namely: 1) activities of PPP Pondokdadap managers and 2) activities of PPP Pondokdadap users (fishermen, traders, tourists, businessmen, and others). As for the environmental aspects, it was divided into three, namely ecological, social and economic aspects. The scale of the frequency and environmental impact factors used were based on Edwards (2004). The final results of the matrix were the average values of the port activity impacts on the environmental aspects. The environmental aspects discussed in this research were only those that had a significant magnitude of environmental impacts, indicated by the average environmental impact value $>3$ (including high and very high environmental impacts) [12].

\section{Management of PPP Pondokdadap's Significant Environmental Aspects}

The management matrix preparation of $P P P$ Pondokdadap's significant environmental aspects aimed to analyze the management of significant environmental aspects occurring and its impacts on the fishing port. From this condition, activity or action planning was undertaken by UPT P2SKP 
Pondokdadap to address and manage the existing significant environmental aspects.

\section{Strategic Description of Interest Levels of PPP Pondokdadap's Significant Environmental Aspects}

This strategic description provides a summary to reinforce the significant environmental aspects with the interest levels of UPT P2SKP Pondokdadap in overcoming the impacts on the significant environmental aspects.

\section{RESULTS AND DISCUSSION}

Based on the preparation and filling of fishing port activity matrix with environmental aspects through data and questionnaires using the SOSEA method, the researchers identified the environmental aspects based on the activity frequency value and the magnitude of impacts resulted. According to the analysis and identification results of PPP Pondokdadap's significant environmental aspects (with the impact value $>3$ ), there were 5 (five) significant environmental aspects obtained in the port, covering 1) waste production of 7.3 (high impact), 2) labor absorption of 7.0 (high impact), 3) water pollution of 6.8 (high impact), 4) ship waste production of 6.6 (high impact) and 5) liquid waste production of 6.0 (high impact). The detail matrix information is presented in Table 1.

To know the environmental management conducted by UPT P2SKP Pondokdadap towards the significant environmental aspects, the researchers also carried out an analysis on the impacts and the management action plans. Strategic and specific questions on the significant environmental aspects of the fishing port would determine the causes, prevailing regulations, obstacles, planned actions, real actions, support and interest levels in the management of PPP Pondokdadap's significant environmental aspects in accordance with the SOSEA procedure, which is further explained in the following Table 2-5.

Table 1. Matrix of Significant Environmental Aspect Calculation

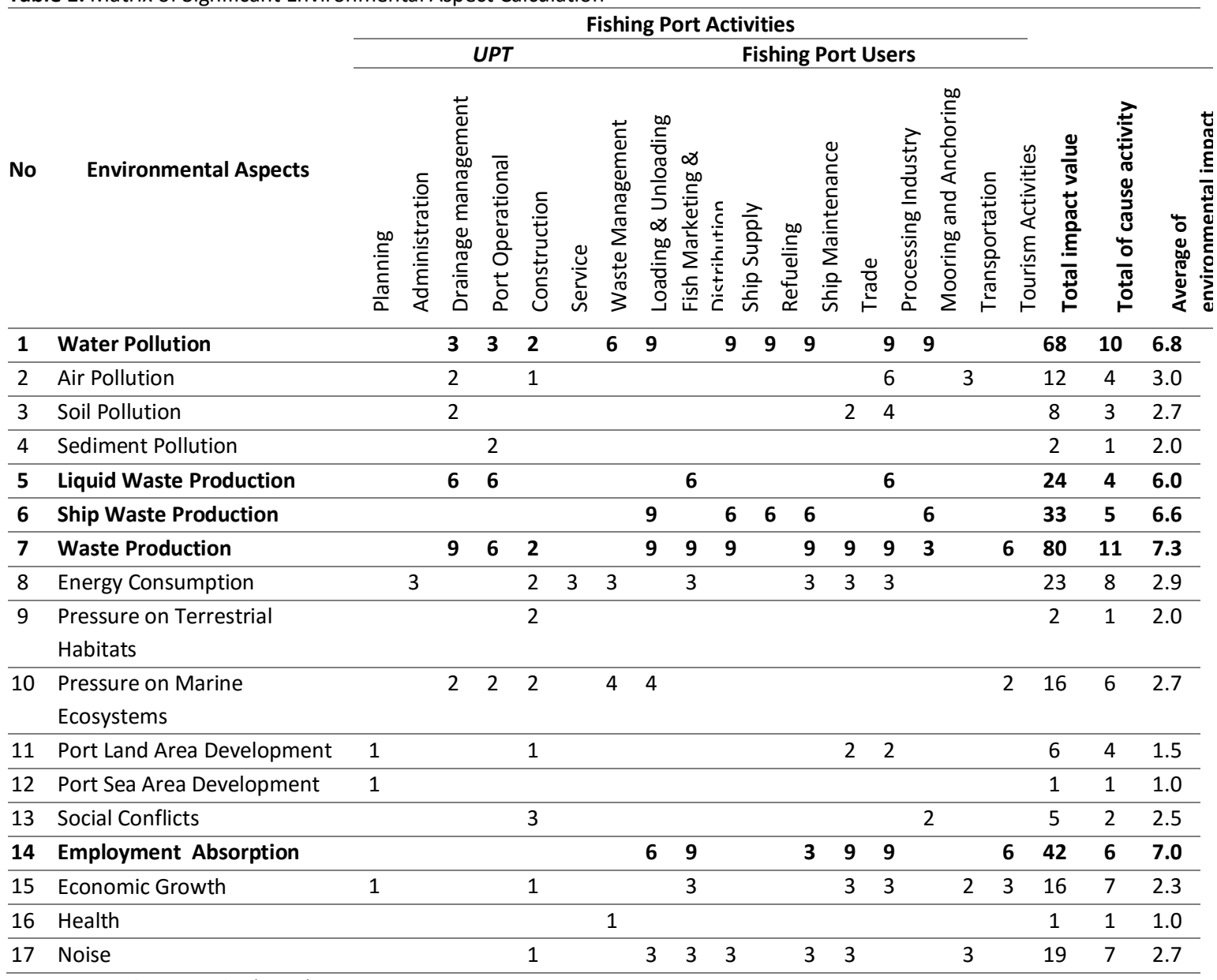

Source: Analysis Results (2018) 
Table 2. Management of Significant Environmental Aspects Based on the Regulation in Indonesia

\begin{tabular}{cll}
\hline No & Environmental Aspects & \multicolumn{1}{c}{ Related Regulations } \\
\hline 1 & Waste Production & $\begin{array}{l}\text { Law of the Republic of Indonesia No. 18 of 2008 on Waste Management } \\
\text { Regulation of the Minister of Health of the Republic of Indonesia Number 44 of 2014 on } \\
\text { Healthy Port and Airport Operation }\end{array}$ \\
\hline 2 & Absorption of Labor & $\begin{array}{l}\text { Government Regulation of the Republic of Indonesia Np. } 33 \text { of } 2013 \text { on Expansion of Job } \\
\text { Opportunities } \\
\text { Regional Regulation of East Java Province No. } 3 \text { of } 2016 \text { on Protection and Empowerment } \\
\text { of Fishermen }\end{array}$ \\
\hline 3 & Water Pollution & $\begin{array}{l}\text { Regulation of the Minister of Environment No. } 05 \text { of 2009 on Port Waste Management } \\
\text { Decree of the Minister of Environment No. } 115 \text { of 2003 on Guidance for Status } \\
\text { Determination of Water Quality } \\
\text { Decree of the Minister of Environment No. 51 of 2004 on Sea Water Quality Standard }\end{array}$ \\
\hline 4 & Ship Waste Production & $\begin{array}{l}\text { Regulation of the Minister of Environment No. } 05 \text { of 2009 on Port Waste Management } \\
\text { Regulation of the Minister of Health of the Republic of Indonesia No. 44 of 2014 on } \\
\text { Healthy Port and Airport Operation }\end{array}$ \\
\hline 5 & Liquid Waste & $\begin{array}{l}\text { Decree of the Minister of Marine Affairs and Fisheries No. 52A/KEPMEN-KP/2013 on } \\
\text { Requirements of Quality and Security Assurance of Fishery Products in Production, } \\
\text { Processing, and Distribution Processes }\end{array}$ \\
\hline
\end{tabular}

Source: Primary Data (2018)

Table 3. Obstacles of Significant Environmental Aspect Management

\begin{tabular}{|c|c|c|}
\hline No & Environmental Aspects & Obstacle Factors \\
\hline 1 & Waste Production & $\begin{array}{l}\text { Sanitary or Cleanliness Facilities and Infrastructure } \\
\text { Coordination and Cooperation } \\
\text { People Social Awareness }\end{array}$ \\
\hline 2 & Labor Absorption & $\begin{array}{l}\text { Facility and Infrastructure Coaching and Development } \\
\text { Concept and Plan Development }\end{array}$ \\
\hline 3 & Water Pollution & $\begin{array}{l}\text { Facilities and Infrastructure } \\
\text { Monitoring Activities } \\
\text { Coordination, Cooperation, and Law Enforcement } \\
\text { People Social Awareness, Lack of Regulation Implementation Understanding }\end{array}$ \\
\hline 4 & Ship Waste Production & $\begin{array}{l}\text { Facilities and Infrastructure } \\
\text { Coordination, Cooperation, and Law Enforcement } \\
\text { People Social Awareness }\end{array}$ \\
\hline 5 & $\begin{array}{l}\text { Liquid Waste } \\
\text { Production }\end{array}$ & $\begin{array}{l}\text { Socialization of Technical Guidance and Regulation } \\
\text { Waste Management Technology } \\
\text { Discipline Enforcement }\end{array}$ \\
\hline
\end{tabular}

Source: Primary Data (2018)

Table 4. Specific Condition of Significant Environmental Aspects

\begin{tabular}{|c|c|c|c|c|c|c|}
\hline \multirow[t]{2}{*}{ No } & \multirow{2}{*}{$\begin{array}{l}\text { Environmental } \\
\text { Aspects }\end{array}$} & \multicolumn{5}{|c|}{ Specific Condition of Significant Environmental Aspects } \\
\hline & & $\begin{array}{c}\text { Development } \\
\text { Planning }\end{array}$ & $\begin{array}{c}\text { Port } \\
\text { Condition }\end{array}$ & $\begin{array}{l}\text { Port } \\
\text { Users }\end{array}$ & $\begin{array}{l}\text { Monitoring } \\
\text { Activities }\end{array}$ & $\begin{array}{c}\text { Management } \\
\text { Procedures }\end{array}$ \\
\hline 1 & $\begin{array}{l}\text { Waste } \\
\text { Production }\end{array}$ & $\mathrm{V}$ & $\mathrm{v}$ & $\mathrm{V}$ & $\mathrm{v}$ & - \\
\hline 2 & $\begin{array}{l}\text { Labor } \\
\text { Absorption }\end{array}$ & $\mathrm{v}$ & $\checkmark$ & $\mathrm{v}$ & $\mathrm{V}$ & - \\
\hline 3 & $\begin{array}{l}\text { Water } \\
\text { Pollution }\end{array}$ & $\mathrm{v}$ & $\mathrm{V}$ & $\mathrm{v}$ & - & - \\
\hline 4 & $\begin{array}{l}\text { Ship Waste } \\
\text { Production }\end{array}$ & $\checkmark$ & V & $\checkmark$ & - & - \\
\hline 5 & $\begin{array}{l}\text { Liquid Waste } \\
\text { Production }\end{array}$ & $\mathrm{v}$ & $\mathrm{V}$ & $\mathrm{V}$ & - & - \\
\hline
\end{tabular}

Source: Primary Data (2018)

From the research results presented in Table 1-4 above, the discussion on significant environmental aspects of PPP Pondokdadap is divided into 3 (three) aspects based on the similarity of impacting activities, covering the aspects of 1) waste production, 2) employment absorption, and 3) water pollution, ship waste production and liquid waste production. 


\section{Waste Production Aspect}

Based on the analysis of the matrix of environmental aspect and activity matrix, it can be obtained that waste production in PPP Pondokdadap is generated from several activities in the port such as loading and unloading, fish marketing and distribution, ship supply, ship maintenance, trade, processing industries, mooring and anchoring, and tourism. The land and sea activities at the fishing port potentially generate garbage and waste potential. These activities may come from offices, ship repairs, shops, stores, industries, loading and unloading at sea, and other sea activities resulting waste and wastewater residual such as fuel and lubricant spills [4].

Based on the field observation, uncontrolled waste conditions in PPP Pondokdadap is often located in the dock area, fish markets, and around Fish Auction Place (TPI). The uncontrolled waste conditions are due to the low awareness of the port users (fishermen, traders, tourists) in taking actions towards the production of garbage and waste, as well as the lack of waste disposals either in terms of quantity and spread location. Another factor causing such conditions occurred is the difference in hygiene or cleanliness conditions of PPP Pondokdadap in the non-fish season and fish season. It is reflected by the relative clean condition in the dock area at the non-fish season turning to be dirty and full of waste at the fish season. Of course, these conditions resulted in big waste problems, including the high rate of waste production, lack of public awareness, people's littering behavior, lack of knowledge of waste and its impacts, and inadequate hygiene public facilities that are easily accessible by people [13]. Based on the above conditions, the main thing in environmental problems is the intention of PPP Pondokdadap in managing waste seriously. Because a significant indicator of waste management is intention with variable types of waste, influence and economic benefits of waste. This intention must be implemented starting from the concept, policy and continuous implementation of waste management [14].

Furthermore, socialization activities on waste management have not been routinely conducted although an activity of 'Declaration to Stop Disposing of Waste to the Sea' was made in May 2017 followed by fishermen and communities around the port. Efforts to raise public awareness to maintain coastal and marine hygiene need to be continuously carried out to preserve the coastal and marine resources from damage caused by human activities, one of which is waste [15]. In addition to socialization activities, PPP Pondokdadap should also improve the activities of maintaining hygiene (cleanliness) and orderliness throughout the port operational areas, and take efforts to reduce, sort, and manage waste.

\section{Employment Absorption Aspect}

Data on the employment absorption aspect in PPP Pondokdadap (2017) suggest that during January - April (non-fish season), there was no ship operating and fish production. This indicates that during the period, the people taking the port as their job field or income source experienced a vacuum of activities or being unproductive temporarily. Based on the data of the number of job types in PPP Pondokdadap as presented in Table 5, it can be seen that within the 4 (four) months, there were 4,511 people losing their livelihood or experiencing a decrease in their income. To minimize the impact resulted from the lack of people productivity at non-fish seasons, PPP Pondokdadap has developed the port area as an interconnected tourism area, including the planned development of the port tourism area, educational activities, fishing tourism, processing industries, craft/ souvenir development, and other tourism activities involving the local community. This tourism area development will support ecotourism activities that have developed around the port. This has a positive impact on the economic, social and environmental indicators of PPP Pondokdadap, because ecotourism prioritizes indigenous peoples in ecosystem management and services [16].

\begin{tabular}{llr}
\multicolumn{2}{c}{ Table } & . Number of Job Types in PPP Pondokdadap \\
\hline No. & Job Types & Number \\
\hline 1 & Fisherman & 3,746 \\
2 & Fish Businessman & 150 \\
3 & Food Stalls & 130 \\
4 & Ojek (Motorcycle Taxi) & 150 \\
5 & Rough Workers & 250 \\
6 & Tour Boats & 10 \\
7 & Shops & 75 \\
\hline & Total
\end{tabular}

Source: PPP Pondokdadap (2017)

These activities are expected to support the productivity sustainability of the people around the port and decrease the people's income difference earned in the non-fish season and fishseason. These activities are also in line with the 
Regulation of East Java Province Number 3 of 2016 on Protection and Empowerment of Fishermen, stating that the Provincial Government shall organize protection and empowerment of fishermen in a planned, directed and sustainable manner to realize the welfare of the community [17].

\section{Water Pollution, Ship Waste Production, and Liquid Waste Production Aspects}

PPP Pondokdadap's significant environmental aspects of Water Pollution, Ship Waste Production, and Liquid Waste Production are related to each other. These aspects are affected by the port development activities (reclamation, dredging, and construction) and routine activities (waste management, loading and discharging, fish marketing and distribution, ship supply, ship maintenance, and management industries). For reclamation, dredging and development activities, basically there have been implementation procedures and work methods applied to minimize the negative impacts on the environment. However, the routine activities have not been running accordingly to the applicable terms and conditions.

According to the data, in 2017, there was an incident of oil waste in the coast around the port reported by the Supervisory Society Group (POKMASWAS). Following up on the findings of incident, inter-agency coordination, involving the Office of Marine Affairs and Fisheries of East Java Province, the Office of Fisheries of Malang Regency, the Ministry of Marine Affairs and Fisheries, Navy Post, Marine Police, Natural Resource Conservation Center, Bhakti Alam Sendangbiru Foundation, and POKMASWAS $G O A L$, has been undertaken to overcome and avoid such a pollution incident. Socialization of the ban on waste (oil and waste) disposal into the sea to all port stakeholders, especially fishermen is considered the most appropriate for the environmental conditions in $P P P$ Pondokdadap. This socialization is done prior to taking direct actions in the field against fishermen who make violations.

Furthermore, the control function of the port water condition has not been implemented. Similarly, the water pollution in $P P P$ Pondokdadap area has not also been measured due to the unmonitored water quality. Although the establishment of Waterwaste Treatment Plant (WWTP) in PPP Pondokdadap has been finished in 2017, it still cannot be operated because there has been no handover. It means that there is no waste management of the activities occurring in the port. Based on the Regulation of the Minister of Marine Affairs and Fisheries of the Republic of Indonesia Number PER.08/MEN/2002 concerning Fishing Port, WWTP is included in port functional facilities, but not yet included in the category of facilities that must exist in fishing ports [1].

This is not in line with Law No. 32 of 2009 on Environmental Protection and Management, explaining that every person has the obligation to maintain the preservation of environmental functions, control environmental pollution and/ or damage, and comply with the provisions on environmental quality standards and/or environmental damage standards [18]. Meanwhile, the Regulation of the Ministry of Environment of the Republic of Indonesia Number 26 of 2012 concerning Technical Guidelines for the Utilization of the Special Allocation Fund for the Environmental Sector of the Fiscal Year of 2013 explains that WWTP is a means and infrastructure for controlling environmental pollution [19]. In addition to having technical functions, WWTP is also expected to increase the awareness of the surrounding community on the environmental quality [20].

According to the SOSEA method-based condition and discussion of significant environmental aspects of PPP Pondokdadap Malang which is classified as class $C$ fishing port in comparison with the research of significant environmental aspects of PPS Nizam Zahman Jakarta which is classified as class A fishing port, there are two similar significant environmental aspects, namely waste production and water pollution aspects. The significant environmental aspects of PPS Nizam Zahman consist of 1) waste production (Impact Factor Value $=4.96$ ); 2) social interaction (Impact Factor Value $=4.83$ ); and 3) Water Pollution (Impact Factor Value $=4.16$ ) [21]. Therefore, fishing port management with the Eco-Fishing Port concept is absolutely necessary to reduce and eliminate significant environmental aspects in fishing ports [22]. Additionally, the implementation of Eco-Fishing Port concept in the management of fishing ports can reduce the negative impacts of fishing port activities on the environment, maintain environmental balance, as well as improve fishery product quality and export potential [23].

In broad outline, the description of the SOSEA method-based management of significant environmental aspects that must be done by UPT 
P2SKP Pondokdadap is to implement the related regulations as presented in Table 2 , considering that the regulations have a legal basis in the implementation. Implementation and enforcement of the existing legislation will have a significant effect in reducing the negative impacts generated by port management on the environment. This condition will directly reduce even eliminate significant environmental aspects in PPP Pondokdadap.

Furthermore, solution steps and planned action fulfillment should also be taken to overcome the obstacles emerging in the management of significant environmental aspects as presented in Table 3 . These steps can be done in the form of the fulfillment of environmental pollution control facilities and the implementation of socialization and coaching to the port users. Therefore, UPT P2SKP Pondokdadap must prioritize the activities related to the port environmental management. As explained in Table 4, significant environmental aspects can affect the development plans, port conditions, and port users. Thus, continuous monitoring and procedural preparation are highly necessary for the management of significant environmental aspects, which have not been implemented by UPT P2SKP Pondokdadap.

\section{CONCLUSION}

The SOSEA analysis conducted in PPP Pondokdadap resulted in 5 (five) significant environmental aspects, namely: waste production, employment absorption, water pollution, ship waste management, and liquid waste production with impact values $>6$ (high impact). These five significant aspects must be the priority of PPP Pondokdadap managers in conducting every plan, program, and activity to realize port management with Eco-Fishing Port concept.

In broad outline, waste production is carried out through the monitoring of the cleanliness and orderliness throughout the port operational area, implementation of waste reduction, sorting and management, port user coaching, sanitary or cleanliness facility and infrastructure improvement, and discipline enforcement. Management of the labor absorption aspect is done by empowering the port functions and the community of fishermen for sustainable tourism activities. Meanwhile, management of the aspects of water pollution, ship waste production and liquid waste production is done by continuous port condition monitoring, discipline enforcement, implementation and application of hygiene standards, water quality monitoring, and integrated WWTP operations.

\section{ACKNOWLEDGMENT}

The authors would like to thank the Head of Education Center for Marine and Fisheries for the support of financing this research activity through the assignment of studying. Thanks are also due to the Directorate General of Marine and Fishery Resources Surveillance of the Ministry of Marine Affairs and Fisheries on the assignment given.

\section{REFERENCES}

[1]. Kementerian Kelautan dan Perikanan Republik Indonesia. 2012. Peraturan Menteri Kelautan dan Perikanan Republik Indonesia Nomor PER.08/MEN/2012 tentang Kepelabuhanan Perikanan. Jakarta.

[2]. Nugraha, R., B. Adhitya, L.O.N. Mbay, dan J. Kusyanto. 2014. Penerapan Konsep Fishing Ecoport untuk Pengembangan Pelabuhan Perikanan di Indonesia. Jurnal Kelautan Nasional 9 (3): 163-169.

[3]. Undang-Undang Republik Indonesia Nomor 45 tahun 2009 tentang Perubahan atas Undang-Undang Nomor 31 tahun 2004 tentang Perikanan.

[4]. Supriyanto. 2013. Analisis Pengelolaan Pelabuhan Perikanan Berwawasan Lingkungan di Pelabuhan Perikanan Samudera Nizam Zachman Jakarta. Jurnal Ilmu Lingkungan 7: 159-179.

[5]. Kementerian Kelautan dan Perikanan Republik Indonesia, 2014. Keputusan Menteri Kelautan dan Perikanan Republik Indonesia Nomor PER.45/KEPMENKP/2014 tentang Rencana Induk Pelabuhan Perikanan Nasional. Jakarta.

[6]. Risnandar. 2013. Pengelolaan Lingkungan di Pelabuhan Perikanan, Studi Kasus di: Pelabuhan Perikanan Nusantara Palabuhanratu. Tesis Magister Sains. Sekolah Pascasarjana Institut Pertanian Bogor. Bogor.

[7]. Kusuma, B.M.A. 2014. The Role of Government in Overcoming Industrial Development Impact towards Environmental Sustainability. JPAL 5 (1): 24-30.

[8]. Darbra, M.R. 2005. Una Nova Metodologia per a L'avaluació de la Destió Ambiental en Ports de Mar. Tesi Doctoral. Centre 
d'Estudis del Risc Tecnològic (CERTEC) Departament d'Enginyeria Química Escola Tècnica Superior d'Enginyeria Industrial de Barcelona. Universitat Politècnica de Catalunya.

[9]. Jaya, M.M., B. Wiryawan dan D. Simbolon. 2017. Keberlanjutan Perikanan Tuna di Perairan Sendangbiru Kabupaten Malang. Jurnal Albacore 1(1): 111-125.

[10]. Kristyarini, A.S., S. Ramdlani, A. Soekirno. Konsep Ekologi-Teknik pada Perancangan Resort di Pantai Sendangbiru Malang. Jurnal Mahasiswa Jurusan Arsitektur 3 (1).

[11]. Luthfi, O.M., P. Pujarahayu, K. Fajar S., A. Wahyudiarto, S.R. Fakri, M. Sofyan, F. Ramadhan, M.A. Ghofur, S. Murian, I. Tovani, Mahmud, D. Adi, F. Abdi. 2016. Biodiversitas dan Populasi Ikan Karang di Perairan Selat Sempu Sendangbiru Kabupaten Malang Jawa Timur. Jurnal Kelautan 9 (1): 43-49.

[12]. Edwards, A.J. 2004. ISO 14001 Environmental Certification Step by Step. Elsevier Butterworth - Heinemann. Burlington, England.

[13]. Mulasari, S.A., Sulistyawati. 2014. Keberadaan TPS Legal dan TPS Ilegal di Kecamatan Godean Kabupaten Sleman. Jurnal Kesehatan Masyarakat 9 (2): 122130.

[14]. Muljaningsih, S., A.K. Galuh. 2018. Intention Model of Waste Management Education Concept based on Green Campus in Brawijaya University. JPAL 9 (2).

[15]. Balai Pengelolaan Sumberdaya Pesisir dan Laut Denpasar. Direktorat Jenderal Pengelolaan Ruang Laut. Kementerian Kelautan dan Perikanan. 2017. Peringatan Coral Triangle (CT) Day di Kabupaten Malang Tahun 2017. http:// bpspldenpasar.kkp.go.id/peringatan-coraltriangle--ct--day-di-kabupaten-malangtahun-2017. Diakses 24 April 2018.

[16]. Butarbutar, R.R., Soemarno. 2012. Community Empowerment Efforts in Sustainable Ecotourism Management in North Sulawesi, Indonesia. JPAL 3 (1): 1-7.

[17]. Peraturan Daerah Provinsi Jawa Timur Nomor 3 Tahun 2016 tentang Perlindungan dan Pemberdayaan Nelayan.

[18]. Undang-Undang Republik Indonesia Nomor 32 tahun 2009 tentang Perlindungan dan Pengelolaan Lingkungan Hidup.

[19]. Kementerian Lingkungan Hidup Republik Indonesia. 2012. Peraturan Menteri Lingkungan Hidup Republik Indonesia Nomor 26 tahun 2012 tentang Petunjuk Teknis Pemanfaatan Dana Alokasi Khusus Bidang Lingkungan Hidup tahun Anggaran 2013.

[20]. Prisanto, D.E., B. Yanuwiadi, Soemarno. 2015. Studi Pengelolaan IPAL (Instalasi Pengolahan Air Limbah) Domestik Komunal di Kota Blitar, Jawa Timur. JPAL 6 (1): 74-80.

[21]. Muninggar, R., E. Lubis, B.H. Iskandar, J. Haluan. 2016. Aspek Lingkungan Signifikan di Pelabuhan Perikanan Samudera Nizam Zachman Jakarta. Jurnal Marine Fisheries 7 (2): 203-210

[22]. J. Dinwoodie, S. Tuck, H. Knowles, J. Benhin and M. Sansom. 2012. Sustainable Development of Maritime Operations in Ports. Business Strategy and the Environment Journal 21: 111-126.

[23]. European Commission. 2015. https://ec.europa.eu/europeaid/blending/ eco-fishing-ports-development-pilotproject_en. Eco fishing ports development pilot project. Diakses 16 Mei 2018. 